Prof. Strahinja Miljković, ${ }^{*} L L . D .$,

Associate Professor,

Faculty of Law, University of Priština,

Temporary head office in Kosovska Mitrovica

Igor Simić, ${ }^{*}$ LL.B.

Teaching Assistant,

UDK: 341.1:35.07(497.115)

Рад примљен: 11.10.2019.

Рад прихваћен: 25.02.2020.

Faculty of Economics, University of Priština,

Temporary head office in Kosovska Mitrovica

\title{
QUASI-LEGAL EFFECTS OF THE LAW NO. 05/L-079 ON STRATEGIC INVESTMENTS OF THE PROVISIONAL INSTITUTIONS OF SELF-GOVERNMENT OF AUTONOMOUS PROVINCE KOSOVO AND METOHIJA ${ }^{* *}$
}

\begin{abstract}
Upon the adoption of Resolution 1244 (1999), the United Nations Interim Administration (UNMIK) gained the status of the guardian of stateowned and societal property of the Republic of Serbia in the territory of the Autonomous Province (AP) of Kosovo and Metohija. For the purpose of this paper, the authors focus on certain regulations issued by the UNMIK administration that were the basis for the creation of a quasi-legal system in the territory of the AP Kosovo and Metohija. However, by adopting Regulations with the force of law, the UNMIK or the UN Secretary-General's Special Representative unilaterally abrogated the formerly existing legal system, thus creating conditions for the establishment of a quasi-legal system independent of the legal system of the Republic of Serbia. UNMIK/REG/1999/24 resulted in the reincarnation of the SFRY-era legal acts. Regulation no. 1999/24 was a guideline in further legal design and normalization of a quasi-legal system in the territory of the AP Kosovo and Metohija. The authors also pay special attention to the Law No. 05/L-079 on Strategic Investments, adopted by the Provisional Institutions of Self-Government of the AP Kosovo and Metohija. The significance of the said legislative act is that it is one in a series of acts that brought about changes in the property law regime concerning state-owned and socially-owned immovable property. However, the full implementation of this Law was facilitated at the time
\end{abstract}

\footnotetext{
*strahinja.miljkovic@pr.ac.rs

*igor.simic@pr.ac.rs

** Рад је изложен на Међународној конференцији „Право и мултидисциплинарност“, одржаној 12-13. 4. 2019. године на Правном факултету у Нишу.
} 
by the adoption of Decision no. 06/134, which provided that all real estate registered in the name of the Socialist Federal Republic of Yugoslavia or the Republic of Yugoslavia, the Socialist Republic of Serbia or the Republic of Serbia and the Socialist Autonomous Province of Kosovo and Metohija was to be registered in the name of the Provisional Institutions of Self-Government of the AP Kosovo and Metohija as the owner of the immovable property.

Keywords: UNMIK, Regulation 1999/1, Regulation 1999/24, quasi-legal system, Law No. 05/L-079 on Strategic Investments, Decision 06/134, Provisional Institutions of Self-Government, AP Kosovo and Metohija, immovable property, privatization.

\section{Introduction}

Ever since the adoption of the UN Security Council Resolution $1244^{1}$ on 10 June 1999, when the territory of the Autonomous Province Kosovo and Metohija (hereinafter: AP Kosovo and Metohija) was placed under provisional administration of the United Nations Interim Administration (UNMIK Mission) on the pretext of protecting human rights, there has been a flanking abuse of this Resolution. Thus, our further consideration of this issue should start from the following statement: "There is nothing wrong in Kosovo and Metohija; the present-day situation is created by a gross violation of the basic principles of international law“ (Милојевић, 2005:245).

The UN Interim Administration abrogated the former legal system. The UN Secretary-General's Special Representative played a significant in establishing a retroactive legal order. The mandate of the UN Special Representative, with the tacit support of the UN and other peacekeeping missions, and even the OSCE, was to confer legislative, judicial and executive powers on the basis of a series of Regulations with executive force of law; it implies all elements as the

1 UN Security Council Resolution 1244 (1999) on the situation relating to Kosovo, retrieved 19 June 2019 from https://peacemaker.un.org/kosovo-resolution1244

2 UNMIK/REG/1999/1 promulgated the authority of the Interim Administration in Kosovo, as follows:

"1.1 All legislative and executive authority with respect to Kosovo, including the administration of the judiciary, is vested in UNMIK and is exercised by the Special Representative of the Secretary-General.

1.2 The Special Representative of the Secretary-General may appoint any person to perform functions in the civil administration in Kosovo, including the judiciary, or remove such person. Such functions shall be exercised in accordance with the existing laws, as specified in section 3, and any regulations issued by UNMIK." - Section 1, UNMIK/REG/1999/1 on the Authority of the Interim Administration in Kosovo (25 July 1999), Retrieved 19 June 2019 from http://www.unmikonline.org/regulations/1999/re99_01.pdf 
substitute of the state (Челић, 2015:241). It should be noted that the UNMIK Administration's behaviour was beyond their jurisdiction and unprecedented in the United Nations practices (Freidrich, 2005:237). The main political objective of the UNMIK Administration was to contribute to establishing "essential autonomy and self-government in Kosovo" (Freidrich, 2005:238) rather than working to create a legal system (quasi-legal system) independent of the Republic of Serbia legal system and contrary to the provisions of UN Resolution 1244.

\section{The Role of the UNMIK Administration in Shaping and Establishing a Quasi-Legal System}

\subsection{UNMIK/REG/1999/1 on the authority of the Interim Administration in Kosovo*3}

UNMIK/REG/1999/1 arbitrarily determined that the laws which were in force in the territory of AP Kosovo and Metohija before 24 March 1999 shall continue to apply in AP Kosovo and Metohija insofar as they do not conflict with internationally recognized human rights standards, ${ }^{4}$ the fulfilment of the mandate given to UNMIK under United Nations Security Council resolution 1244 (1999), or the present or any other regulation ${ }^{5}$ issued by UNMIK. ${ }^{6}$ To some extent, this Regulation respected the principle of inviolability of property. The UNMIK administration was given the status of a guardian of state-owned and societal property Federal of Republic of Yugoslavia respectively Republic of Serbia. The UNMIK administration was authorized to administer movable and immovable property, including funds, bank accounts, and other property of or registered

3 Kosovo* - "This designation is without prejudice to positions on status, and is in line with UNSC Resolution 1244 and the ICJ Opinion on the Kosovo declaration of independence", Retrieved 20 June 2019 from https://www.srbija.gov.rs/kosovo-metohija/168200

4 "In exercising their functions, all persons undertaking public duties or holding public office in Kosovo shall observe internationally recognized human rights standards and shall not discriminate against any person on any ground such as sex, race, colour, language, religion, political or other opinion, national, ethnic or social origin, association with a national community, property, birth or other status". - Section 2, UNMIK/REG/1999/1.

5 In the performance of the duties entrusted to the interim administration under United Nations Security Council resolution 1244 (1999)), UNMIK will, as necessary, issue legislative acts in the form of regulations. Such regulations will remain in force until repealed by UNMIK or superseded by such rules as are subsequently issued by the institutions established under a political settlement, as provided for in United Nations Security Council resolution 1244 (1999)". - Section 4, UNMIK/REG/1999/1.

6 Section 3, UNMIK/REG/1999/1. 
in the name of the Federal Republic of Yugoslavia or the Republic of Serbia, or any of its organs which is located in the territory of Kosovo.?

\subsection{UNMIK/REG/1999/24 on the Law Applicable in Kosovo*}

The situation proclaimed by UNMIK/REG/1999/1 did not last long. The Regulation UNMIK/REG/1999/248 stipulated that the law applicable in Kosovo* was "the law in force in Kosovo on 22 March 1989". ${ }^{9}$ This Regulation actually restored and reinstated the legal system which had been developed and used in AP Kosovo and Metohija up to that point, particularly in the area of property relations. In effect, it was a reincarnation of the legal acts form the era of the SFR Yugoslavia. Regulation 1999/24 served as a guideline for further legal design and normalization of a quasi-legal system in the territory of the AP Kosovo and Metohija. The Regulation urged that "all persons undertaking public duties or holding public offices in Kosovo shall observe internationally recognized human rights standards" and anti-discrimination standards in law enforcement. ${ }^{10}$ Yet, all subsequent decrees of the Special Representative, and especially those concerning property and rights arising thereof, rested on the "sacred principle of discrimination". The principle of discrimination became and still remains the undisputed basis for the regulation of property relations in the territory of the AP Kosovo and Metohija. The enactment of this Regulation created conditions for permanent change of property relations in economic entities. The property transformation pertaining to legal entities in the period between 22 March 1989

7 Section 6, UNMIK/REG/1999/1.

8 UNMIK/REG/1999/24 on the Law Applicable in Kosovo (12 December 1999), Retrieved 20 June 2019 from http://www.unmikonline.org/regulations/1999/re99_24.pdf

9 Under UNMIK/REG/1999/24, Applicable Law is regulated as follows:

"1.1 The law applicable in Kosovo shall be: (a) (a) The regulations promulgated by the Special Representative of the Secretary-General and subsidiary instruments issued thereunder; and (b) (b) The law in force in Kosovo on 22 March 1989. In case of a conflict, the regulations and subsidiary instruments issued thereunder shall take precedence.

1.2 If a court of competent jurisdiction or a body or person required to implement a provision of the law determines that a subject matter or situation is not covered by the laws set out in section 1.1 of the present regulation but is covered by another law in force in Kosovo after 22 March 1989 which is not discriminatory and which complies with section 1.3 of the present regulation, the court, body or person shall, as an exception, apply that law."- Section 1 (Applicable Law), UNMIK/REG/1999/24.

10 Section 1. (paragraphs 1.3 and 1.4), UNMIK/REG/1999/24. 
and 10 June 1999 was negated, ${ }^{11}$ with the re-implementation of reincarnated legal texts. ${ }^{12}$

\section{Law No. 05/L-079 on Strategic Investments}

In the period following the unilateral declaration of independence of Kosovo, the UNMIK administration began the process of delegating legislative authority to the Provisional Institutions of Self-Government of Autonomous Province Kosovo and Metohija (hereinafter: the PISG AP Kosovo and Metohija) and providing logistic support in the process of rounding up the quasi-legal space in the territory of the AP Kosovo and Metohija. By acquiring new competences, which were primarily of an administrative nature up to that point, the PISG AP Kosovo and Metohija passed and adopted laws affecting the change of property regime in the territory of the AP Kosovo and Metohija. ${ }^{13}$

The establishment of the Kosovo Trust Agency ${ }^{14}$ and the Kosovo Privatization Agency ${ }^{15}$ contributed to privatizing businesses, ${ }^{16}$ while the adoption of the Law No. 05/L-079 on Strategic Investments ${ }^{17}$ (hereinafter: Law No. 05/L-079) completed the process of legal usurpation of immovable property owned by: a) socially and publicly owned business entities (companies), and b) state property of the Republic of Serbia. When the Law No. 05/L-079 entered into force, the practice of de facto usurpation and nationalization of assets of the Republic of Serbia in the territory of AP Kosovo and Metohija was continued.

11 It should be noted that the property transformation relating to legal entities is considered to be: a) merger; b) transformation; c) (re) registration; d) incorporation as a joint stock company or as a limited liability company, or a partnership or other legal entity; e) bankruptcy, liquidation, insolvency, for the purpose of reorganization into a clear form or other entity, or any other event or proceeding that has altered any of the following with respect to that person: its legal identity, form or nature, or form or the nature of his property or capital, his headquarters, and when any such event or proceeding or any portion thereof occurred at any time between 22 March 1989 and June 2002, Retrieved 25 June 2019 from http:// www.kta-kosovo.org/

12 The Law on Companies, "Official Gazette of the SFRY", no. 77/88, 40/89, 46/90 and 61/90.

13 It should be noted that the laws adopted by the PSIG have their legal source in UNMIK Regulations.

14 UNMIK/REG/2002/12 on the Establishment of the Kosovo Trust Agency (13 June 2002), Retrieved 20 July 2019 from http://www.unmikonline.org/regulations/2002/RE2002_12.pdf 15 Law No. 03/L-067 on the Privatisation Agency of Kosovo*, Retrieved 20 July 2019 from https://gzk.rks-gov.net/ActDetail.aspx?ActID $=2542$

16 From its establishment in 2003 until 23. 01. 2008, the Kosovo Trust Agency conducted 30 privatization cycles, Retrieved 20 July 2019 from http://kta-kosovo.org/html_sr/index.php 17 Law No. 05/L-079 on Strategic Investments in Kosovo* - Law No. 05/L-079, Retrieved 28 July 2019 from https://gzk.rks-gov.net/ActDetail.aspx?ActID=13319 


\subsection{What is the subject of a strategic investment agreement?}

The subject matter of a strategic investment agreement is only immovable property. Immovable property is to be considered "any type of immovable property registered in the name of any publicly or socially-owned enterprise, ${ }^{18}$ administered by any public authority". ${ }^{19}$

In reviewing the legal provisions, definitions of what should be considered a socially-owned and publicly-owned enterprise are also important. A socially owned enterprise is considered "any enterprise under the administration of Privatization Agency of Kosovo* in compliance with the relevant Law on Privatization Agency of Kosovo*”. ${ }^{20}$ There is no ambiguity as for the definition of a publicly-owned enterprise, which is designated as "any enterprise defined in the lists attached to the relevant Law on Publicly Owned Enterprises". ${ }^{21}$ The aforementioned formulation of what is and what is to be considered a sociallyowned and publicly-owned enterprise opens space to delegate the right to the Strategic Investment Commission to dispose of the assets of these companies.

However, when determining the subject matter of a strategic investment agreement, the law provides that immovable property should also be considered property registered on behalf of any public authority or agency in Kosovo*. In addition to the precise definition that the subject matter of the strategic investment agreement is immovable property owned by social and public enterprises, a public authority or agency, the subject of the agreement may also include forests and forest land managed by the Kosovo Forest Agency. ${ }^{22}$

\subsection{Who can appear in the role of an investment entity?}

The question that raises a number of controversies and seeks an answer is the question of who can appear as an investment entity, or who can be an investor. The following persons may appear as an investment entity: a) a foreign investor, and b) a domestic investor. A foreign investor can be: a) any natural person who is citizen of a foreign country, b) any natural person who is a citizen of Kosovo*, but has residence abroad, and c) a legal person established according to the Law of a

18 The precise legal definition of this term is important because the immovable property of socially-owned and publicly-owned enterprises makes the largest share of the real estate in the territory of the AP of Kosovo and Metohija, and the economic and market value of the immovable property of these enterprises was the initial basis for the adoption of the Strategic Investments Law.

19 Article 3 (1.7.) Law No. 05/L-079.

20 Article 3 (1.7.1.) Law No. 05/L-079.

21 Article 3 (1.7.2.) Law No. 05/L-079.

22 Article 3 (1.7.) Law No. 05/L-079. 
foreign country. ${ }^{23}$ Although the above provision is transparent at first glance, it must be assumed that its interpretation implies that only an entity domiciled or registered in a state that has recognized the unilateral independence of Kosovo* can appear as a foreign investor.

A domestic investor is defined as "any business organization established in Kosovo*, and natural persons who are citizens of Kosovo*". ${ }^{24}$ It is exactly in the part determining who may appear as a domestic investor and determining their status that the said provision conflicts with the provisions of UN Resolution 1244 guaranteeing the territorial integrity of the Republic of Serbia. It can be concluded that although UN Resolution 1244 is still in force, legal entities and natural persons from the territory of the Republic of Serbia do not have the status of domestic investors under the provisions of the Law No. 05/L-079. Even if there were a possibility for Serbian legal entities and natural persons to appear as domestic investors, under the "governing principle of discrimination" that has become a sacred rule in Kosovo*, such and such entities are undesirable or their bids would be rejected by the Commission in the strategic investment process.

\subsection{Investment project approval process}

An investor who wishes to ensure that his project obtains the status of a strategic project ${ }^{25}$ or strategic investment ${ }^{26}$ is obliged to submit a written request to the Investment Agency. Upon submission of the request, the Government of the PISG AP Kosovo and Metohija decides on the approval or rejection of the application for obtaining the strategic investment status. After the request is approved by the Governments of the PISG AP Kosovo and Metohija, the InterMinisterial Committee (hereinafter referred to as: the Committee) enters into negotiations on the conclusion of the Strategic Investment Agreement. The members of the Committee are: 1) Minister of Trade and Industry, presiding; 2) Minister of Finance; 3) Minister of Environment and Spatial Planning; 4) Minister of Agriculture, Forestry and Rural Development; 5) Minister of Economic Development; 6) One Minister from other non-majority community in Kosovo*; 7) Mayor of the Municipality in which a strategic investment is implemented; 8)

23 Article 3 (1.9.) Law No. 05/L-079.

24 Article 3 (1.10.) Law No. 05/L-079.

25 Strategic Project is defined as "any private and public-private investment project which meets the criteria determined under this Law" - Article 3 (1.4.) Law No. 05/L-079.

26 Strategic Investment is defined as "the status proposed by the Strategic Investments Committee and approved by the Government of Kosovo*, which is given to investment projects, qualified as strategic under this Law, throughout the phases of implementation and operation of the strategic project in the territory of the Kosovo.*" - Article 3 (1.2.) Law No. 05/L-079. 
Minister of the Ministry in which a strategic investment is implemented; and 9) General State Advocate. ${ }^{27}$

It should be noted that although the Mayor in whose territory the investment project is being implemented is one of the members of the Committee, the Committee makes recommendations by simple majority of votes. ${ }^{28}$ The failure to veto by the mayor during voting (especially in the territory inhabited by Serbs and other non-Albanians where no project can be implemented without their consent), is resulting in the denial of the independent right to dispose of immovable property subject to the investment project.

However, despite the quasi-transparency embodied in the Committee's work, the Government of the PISG AP Kosovo and Metohija may enter into direct negotiations for the conclusion of Strategic Investments Agreements without being subject to the procedures for obtaining the status of strategic investments or public procurement procedures. In order to enter into direct negotiations, it is necessary to have an international agreement between the PISG AP Kosovo and Metohija and or one or more other countries or international organizations. ${ }^{29}$ The above-mentioned provision, which is primarily political in nature, excludes the public and lacks procedural transparency, and limits the legal and political mechanisms of the Republic of Serbia in the process of protecting state-owned and socially-owned property and property of publicly-owned enterprises.

\subsection{Transfer of the right to use the property to the investment entity}

Article 18 (1) of the Law No. 05/L-079 states: “Disposal with immovable property of Kosovo* to implement projects related to strategic investments shall be regulated by laws dealing with governance and use of state and public property, the property rights, the law on bonds and laws governing the use and disposition of property." ${ }^{30}$ In accordance with Article 18 (2), the Government of the PISG AP Kosovo and Metohija disposes of all immovable property, including: a) forests and forest land; b) agricultural land, and c) public roads. It should be noted that the Government of the PISG AP Kosovo and Metohija is involved in direct negotiations and, in order to implement a strategic investment project, it may use real estate in accordance with Article 4 (paragraphs 1-6) of the Law No. 05/L-079. ${ }^{31}$

In order to implement a strategic investment project, the Government of the PISG AP Kosovo and Metohija may transfer to an investment entity the right to use:

27 Article 6 (2) Law No. 05/L-079.

28 Article 6 (3) Law No. 05/L-079.

29 Article 4 (5) Law No. 05/L-079.

30 Article 18 (1) Law No. 05/L-079.

31 Article 18 (2) Law No. 05/L-079. 
a) immovable social property under the Law on Expropriation of Immovable Property, and b) immovable public property. ${ }^{32}$ However, in order to ensure such causality, it is necessary that in both cases the Assembly of the PISG AP Kosovo and Metohija decides (by a simple majority vote) on assignment of assets to be used by an investment entity. The Government of PISG AP Kosovo and Metohija may also transfer the right to use the property owned by public enterprises to the investment entity, in compliance with the by-laws adopted in accordance with the Law No. 05/L-079 and relevant provisions of the Public Enterprises Act. ${ }^{33}$

The right to use immovable socially-owned and publicly-owned assets is limited in time. The duration of the right to use the property by the investing entity is determined by the investment agreement, which shall not exceed the maximum period of ninety-nine (99) years. In certain circumstances, if foreign or domestic capital has been invested in the property for the construction of buildings and buildings that are actively used for business purposes, the responsible public authority has the right to give its consent for the extension of the right to use the property for another period with a reasonable time limit. ${ }^{34}$ These provisions envisage a maximum term (term of contract) but they do not provide for a minimum duration of the right to use the property. This part gives rise to a number of questions, one of which is the question of what is considered an extension of the right to use the property for a reasonable period.

We are of the opinion that these provisions constitute a flagrant violation of international law, regardless of whether the time period of concluding the agreement is one day or 99 years, because the status of the APKM has not been finally resolved and all its movable or immovable assets are still owned by the Republic of Serbia.

\section{Decision No. 06/134}

Last but not least, Decision no. 06/134 35 has far-reaching implications for the legal status of socially-owned and publicly-owned companies of Republic of Serbia in the territory of the AP Kosovo and Metohija. The adoption of Decision no. $06 / 134$ was justified by the question of succession of immovable property and rectification of cadastral records in order for Kosovo* to be registered as the owner of properties still registered in the name of SR Yugoslavia and Republic of Serbia; but, this question was raised again during the consultation stage

32 Article 22 Law No. 05/L-079.

33 Article 23 Law No. 05/L-079.

34 Article 24 (1 and 2) Law No. 05/L-079.

35 Decision no. 06/134 of the Government of Kosovo* (01 03. 2017), Retrieved 29 August 2019 from www.kryeministri-ks.net/repository/docs/134_odluke_134.docx 
of drafting the strategy on property rights in Kosovo*. This process began in 2015 and was led by the Ministry of Justice Kosovo* with the support of USAID Kosovo*. In the context of the first thematic group, which was responsible for analysing legislation regarding property and legal rights in Kosovo*, the problem of property registered in the name of SR Yugoslavia and Republic of Serbia was identified and it was recommended that this property be treated according to the international law (by referring to the 1983 Vienna Convention on the Succession of States in Respect of State Property, Archives and Debts). ${ }^{36}$ The Working Group highlighted that "the fact that there is still immovable property in Kosovo* which, despite the rules of international law, is registered in the name of SR Yugoslavia and Republic of Serbia affects public property of Kosovo*, creates legal uncertainty and impedes the use of these properties for the needs of economic and social development of Kosovo." ${ }^{37}$ By referring to the rules of international law on state succession, and pursuant to the Vienna Convention on the Succession of States, the PISG AP Kosovo and Metohija unilaterally declared itself as a legal successor of Republic of Serbia.

The quasi-legal effect of the Decision no. 06/134 is that all real estate registered in the name of the Socialist Federal Republic of Yugoslavia or the Republic of Yugoslavia, the Socialist Republic of Serbia or the Republic of Serbia and the Socialist AP Kosovo and Metohija, including but not limited to their national, administrative, military bodies and former social-political organizations, has been registered in the name of the PISG AP Kosovo and Metohija as the owner of immovable property. ${ }^{38}$ It is anticipated that all necessary actions will be taken to register the said property in the cadastre. ${ }^{39}$ Finally, it can be stated that Decision No. 06/134 creates all necessary conditions for full implementation of the Law No. 05/L-079 Strategic Investments, creating all quasi-legal conditions for de facto usurpation of assets.

\section{Conclusion}

In the period following the unilateral declaration of independence of Kosovo, the UNMIK administration delegated legislative authority to the PISG of AP Kosovo and Metohija and often provided logistic support in the process of rounding

36 Vienna Convention on the Succession of States in Respect of State Property, Archives and Debts (1983), United Nations Document A/CONF. 117/14, Retrieved 30 August 2019 from http://legal.un.org/ilc/texts/instruments/english/conventions/3_3_1983.pdf

37 Reasoning of the Ministry of Justice, Retrieved 18 August 2019 from https://md.rks-gov. net/page.aspx?id=3,15,1710

38 Art. 1, Decision no. 06/134.

39 Art. 2, Decision no. 06/134. 
up the quasi-legal system. Having acquired new competencies, the Provisional Institutions of Self-Government AP Kosovo and Metohija passed and adopt laws that had a significant impact on changing the ownership regime of property located in the territory of the AP of Kosovo and Metohija. The adoption of the Law Strategic Investments by the PSIG AP Kosovo and Metohija facilitated the process of legal usurpation of immovable property, and continued the practice of de facto usurpation and nationalization of property of the Republic of Serbia in favour of the self-proclaimed Kosovo*. It should be noted that the subject of strategic investment legislation and agreements was only the real estate, either socially or state-owned immovable property of the Republic of Serbia. On the basis of facts presented in this paper, we can conclude that the Republic of Serbia must use all its legal and political resources to protect its assets, regardless of the prevailing endeavours to round off the development of a quasi-legal system in the territory of the AP Kosovo and Metohija.

\section{References}

Vicovac, R. D. (2013). Challenges in Providing Legal Aid to Displaced Persons Following Armed Conflict: Lessons Learned from Kosovo, Journal of Human Rights Practice (Vol 00| Number 00| Month 2013| pp. 1-12) (Electronic version). Retrieved 20 September 2019 from http://jhrp.oxfordjournals.org/

Гајић, В. А. (2018). Међународноправни статус Косова и метохије и придруживање Србије Европској Унији, Београд: Правни факултет Универзитета у Београду.

Милојевић, М. (2005). Срби на Косову и Метохији и начела међународног права, (Косовска Митровица 27-29. мај 2005), Српска академија наука и уметности, Београд (219-248).

Челић, Д. (2015). Правни сист ем и заштита од дискриминације, Дискриминацијом против „Дискриминације“ -Дискриминативне одлуке УНМИК-а („Комисије за стамбена и имовинска питања“), Зборник радова, Прва свеска, Правни факултет, Универзитет у Приштини - Косовска Митровица.

Jürgen, F. (2005). UNMIK in Kosovo: Struggling with Uncertainty, Max Planck Yearbook of United Nations Law,Vol. 9 (225-293).

Legal documents

Decision No. 06/134 of the Government of Kosovo (01 03. 2017), Retrieved 29 August 2019 from www.kryeministri-ks.net/repository/docs/134_odluke_134. docx 
Law No. 05/L-079 on Strategic Investments in Kosovo*, Retrieved 28 July 2019 from https://gzk.rks-gov.net/ActDetail.aspx?ActID=13319

Law No. 03/L-067 On the Privatization of Kosovo*, Retrieved 20 July 2019 from https://gzk.rks-gov.net/ActDetail.aspx?ActID $=2542$

Law on Company "Official Gazette of the SFRY", no. 77/88, 40/89, 46/90 and 61/90.

UN Security Council Resolution 1244 (1999) on the situation relating to Kosovo, UN Peacemaker, Retrieved 20 June 20192019 from https://peacemaker.un.org/ kosovo-resolution1244

UNMIK/REG/1999/1 On the Authority of the Interim Administration in Kosovo (25 July 1999); Retrieved 20 June 2019 from http://www.unmikonline.org/ regulations/1999/re99_01.pdf

UNMIK/REG/2002/12 on the Establishment of the Kosovo Trust Agency (13 June 2002), Retrieved 20 July 2019 from http://www.unmikonline.org/regulations/2002/RE2002_12.pdf

UNMIK/REG/1999/24 On the Law Applicable in Kosovo (12 December 1999), Retrieved 20 June 2019 from http://www.unmikonline.org/regulations/1999/ re99_24.pdf

Vienna Convention on the Succession of States in Respect of State Property, Archives and Debts (1983), United Nations Document A/CONF. 117/14, Retrieved 30 August 2019 from http://legal.un.org/ilc/texts/instruments/english/ conventions/3_3_1983.pdf

Kosovo Trust Agency, Retrieved 20 July 2019 from http://kta-kosovo.org/html_ sr/index.php

Ministry of Justice, Retrieved 18 August 2019 from https://md.rks-gov.net/ page. aspx?id=3,15,1710

Vlada Republike Srbije, Dogovor o međusobnom predstavljanju i saradnji, Retrieved 20 June 20192019 from https://www.srbija.gov.rs/kosovo-metohi$\mathrm{ja} / 168200$ 


\title{
Др Страхиња Миљковић,
}

Ванредни професор Правног факултета,

Универзитет у Приштини са привременим

седиштем у Косовској Митровици

\section{Игор Симић,}

Асистент Економског факултета,

Универзитет у Приштини са привременим

седиштем у Косовској Митровици

\section{КВАЗИ-ПРАВНА ДЕЈСТВА ЗАКОНА БР. 05/Л-079 О СТРАТЕШКИМ ИНВЕСТИЦИЈАМА ПРИВРЕМЕНИХ ИНСТИТУЦИЈА АУТОНОМНЕ ПОКРАЈНЕ КОСОВА И МЕТОХИЈЕ}

\begin{abstract}
Резиме
На основу Резолущије 1244 Привремена управа УН-а (УНМИК) има статус старатеља над државном и друштвеном имовином. Ипак, УНМИК аброгира ретрокативно затечени правни систем, стварајући услове за успостављање правног система независног од правног система Р. Србије. За потребе рада аутори посебну пажњу посвећује и Закону о стратешким инвестицијама донетог од стране Привремених институција АП Косова и Метохије. Значај наведеног закона је да представља још један у низу аката који за последицу има промене у својинско-правном режиму државне и друштвене имовине (непокретне имовине привредноправних субјеката). Ипак, потпуна примена закона је постала могућа тренутком доношења Одлуке бр. 06/134. Одлуком бр. 06/134 омогућава се да све некретнине регистроване на име Социјалистичке Федеративне Републике Југославије или Републике Југославије, Социјалистичке Републике Србије, односно Републике Србије и Социјалистичке Аутономне Покрајине Косово се региструју на ПИС Косова и Метохије као власника непокретности.
\end{abstract}

Кључне речи: УНМИК, Уредба 1999/1, Уредба 1999/24, квази правни систем, Закон бр. 05 /Л-079 о стратешким инвестицијама, Одлука бр. 06/134, привремене институције самоуправе, АП Косово и Метохија, непокретна имовина, приватизација. 